\title{
Strategi Pembelajaran Yang Mendukung Kemampuan Komunikasi Matematik
}

\author{
Rahma Hayati Siregar* \\ Email: rahma@iain-padangsidimpuan.ac.id \\ Fakultas Tarbiyah dan Ilmu Keguruan IAIN Padangsidimpuan
}

\begin{abstract}
Mathematical communication is the ability of a person in terms of explaining an algorithm and unique ways to solve problems, the ability of students to construct, and explain the presentation of real word phenomena in graphs, word/sentence, equation, tables or the ability of students to give assumstions about geometry image. Learning strategies that support mathematical communication skills is: Small-Group-Work Strategy, Group, Cooverative Learning, Think-Pair-Share Strategy, and Think-Talk-Write Strategy.
\end{abstract}

Keywords: mathematical communication, learning strategies, small-group-work, cooverative learning, think-pair-share, think-talk-write

\begin{abstract}
Abstrak
Komunikasi matematik adalah potensi seseorang dalam hal memaparkan suatu algoritma dan cara tertentu untuk menyelesaikan masalah, kesanggupan siswa mengkontruksi dan memaprkan sajian suatu kejadian dunia nyata secara grafik, kata-kata/kalimat, persamaan, tabel dan sajian secara fisik atau kemampuan siswa memberikan dugaan tentang gambar-gambar geometri. Strategi pembelajaran yang mendukung kemampuan komunikasi matematik diantaranya adalah: Strategi Small-Group-Work, Cooverative Learning, Strategi Think-PairShare, dan Strategi Think-Talk-Write.
\end{abstract}

Kata Kunci: komunikasi matematik, strategi pembelajaran, small-group-work, cooverative learning, think-pair-share, think-talk-write

\footnotetext{
${ }^{*}$ Correspondence:

Email: rahma@iain-padangsidimpuan.ac.id
} 


\section{A. PENDAHULUAN}

Matematika adalah ilmu pasti dan real, yaitu matematika menjadi ilmu nyata yang bisa diaplikasikan secara langsung dalam aktivitas sehari-hari, dalam berbagai bentuk. Bahkan, tanpa disadari ilmu matematika sering kita aplikasikan untuk menyelesaikan setiap problem kehidupan. Sehingga matematika merupakan ilmu yang benar-benar menyatu dalam aktivitas sehari-hari dan nyata dibutuhkan oleh setiap individu, baik untuk dirinya sendiri maupun berintekrasi dengan sesama manusia. ${ }^{1}$

Pada kenyataannya, tidaka masuk akal jika sesuatu yang sering digunakan dalam kehidupan kita sehari-hari, namun pada kenyataanya itu benar-benar tidak disukai. Maka dapat disimpulkan yang membuat matematika kelihatan sulit dipahami dan menjadi hal yaang menakutkan di kalangan siswa adalah karena pemahamannya. Memahami ilmu matematika adalah sebagai salah satu upaya mengenal matematika merupakan hal penting. Karena, pemahaman sangat berkaitan dengan persepsi seseorang atau anggapan yang terbentuk. Jika persepsi seseoarng terhadap matematika itu rumit, maka orang cenderung memahami matematika sebagai sesuatu hal yang sangat sulit. Oleh sebab itu, baik siswa, guru, maupun orang tua, seharusnya memiliki pemahaman yang tepat terhadap ilmu matematika ini.

Hakikat pembelajaran matematika yaitu suatu aktivitas mental untuk memahami arti dan hubungan-hubungan begitu juga dengan simbol-simbol, kemudian diterapkannya pada situasi yang real. Schoenfeld mengartikan belajar matematika dikaitkan dengan apa dan bagaimana menggunakannya dalam membuat keputusan untuk memecahkan masalah atau problematika. ${ }^{2}$

Banyak usaha telah dilakukan pemerintah untuk meningkatkan mutu pendidikan matematika di Indonesia. Namun kenyataannya, sampai saat ini hasilnya belum begitu memuaskan atau menggembirakan, bahkan dapat dikatakan menyedihkan. Kenyataan ini dapat dilihat dari berbagai indikator hasil belajar,

\footnotetext{
${ }^{1}$ Raodatol Jannah, Membuat Anak Cinta Matematika dan Eksak Lainnya (Jogyakarta: Diva Press, 2011), hlm. 23.

${ }^{2}$ Hamzah, B. Uno, Model Pembelajaran Menciptakan Proses Belajar Mengajar Yang Kreatif dan Efektif (Jakarta: Bumi Aksara, 2008), hlm. 130.
} 
yaitu dalam Ujian Nasional (UN), dalam sejumlah penelitian, dan dalam kontes Internasional matematika seperti yang dilaporkan oleh The Third International Mathematic and Sgience Study.

Fakta tersebut di atas menunjukkan bahwa berbagai macam pendekatan, gagasan atau inovasi dalam dunia pendidikan matematika yang sampai pada saat ini diaplikasikan secara luas ternayata belum dapat memberikan perubahan positif yang berarti dan memuaskan, baik dalam proses kegiatan pembelajaran matematika di sekolah maupun meningkatkan kualitas pendidikan matematika pada umumnya. Di sisi lain, banyak juga yang masih menganut pandangan Transfer Of Knowledge dalam pembelajaran matematika masa kini. Pola berpikir ini berpendapat bahwa siswa merupakan sasaran belajar, akhirnya dalam proses pembelajaran berbagai usaha lebih banyak dilakukan oleh guru, mulai dari mencari, mengumpulkan, memyelesaikan dan menyampaikan informasi diberikan agar peserta didik mendapatkan pengetahuan. ${ }^{3}$

Fakta yang dikemukakan di atas telah diungkapkan juga oleh Ruseffendi, bahwa bagian terbesar dari matematika yang dipelajari siswa di sekolah tidak diperoleh melalui eksplorasi matematik, tetapi melalui pemberitahuan. Pembelajaran matematika tersebut disebut dengan model pembelajaran konvensional atau model pembelajaran biasa, karena keadaan kelas masih dikuasai oleh guru dan fokus pembelajaran ada pada keterampilan tingkat rendah.

Pembelajaran konvensional/biasa ini menitikberatkan pada drill menyelesaikan soal-soal atau drill dengan melakukan pengulangan prosedur serta lebih banyak menggunakan rumus atau algoritma tertentu. Setidaknya ada dua konsekuensi. Pertama, keadaan siswa kurang aktif dan model pembelajaran ini kurang menanamkan pemahaman konsep sehingga kurang menimbulkan sikap kritis. Kedua, jika siswa diberikan soal yang berbeda dengan soal latihan, siswa akan kebingungan karena tidak tahu harus memulai dari mana ia bekerja.

Dalam hal menghadapi pekembangan dan kemajuan ilmu pengetahuan dan teknologi yang semakin modern atau maju, model pembelajaran matematika di

${ }^{3}$ Bansu I. Ansari, Komunikasi Matematik, Strategi Berpikir dan Manajemen Belajar, (Banda Aceh: Yayasan Pena, 2016), hlm. 2. 
kelas perlu diperbaharui (transfer of knowledge), tetapi sebagai pemicu siswa belajar (stimulation of learning) supaya dapat mengkontruksi sendiri pengetahuan melalui berbagai kegiatan seperti pemecah problematika, penalaran dan berkomunikasi (doing math), sebagai bahan pelatihan berpikir kritis dan kreatif. Dalam KTSP (2006) ditekankan bahwa Tujuan Pembelajaran Matematika salah satunya adalah siswa mampu membahasakan atau mengkomunikasikan gagasan dengan simbol, tabel, diagram, atau media lain untuk memperjelas keadaan atau masalah.

Schoen, Baen dan Ziebarth mengungkapkan bahwa komunikasi matematik adalah potensi seseorang dalam hal memaparkan suatu algoritma dan cara khas untuk pemecahan problematika, potensi siswa mengkontruksi dan menjelaskan bahan fenomena dunia real secara grafik, kata-kata/kalimat, persamaan, tabel dan sajian secara fisik atau kemampuan siswa memberikan dugaan tentang gambargambar geometri. ${ }^{4}$

Baroddy memaparkan sedikitnya ada dua alasan yang sangat penting, mengapa komunikasi dalam matematika perlu dimunculkan di kalangan siswa. Pertama, mathematics as language, artinya matematika bukan hanya sekedar menentukan pola , menyelesaikan problematika atau menarik kesimpulan, tetapi matematika adalah sebagai suatu alat yang berharga untuk mengkomunikasikan berbagai ide secara jelas, tepat dan cermat. Kedua, mathematic learning as social activity; artinya, sebagai kegiatan kemasyarakatan dalam pembelajaran matematika, matematika juga sebagai wahana interaksi antar siswa, dan juga komunikasi antara guru dan siswa. Hal ini merupakan bagian yang penting untuk mempercepat pemahaman matematik siswa. Jadi, dapat disimpulkan, komunikasi matematik baik sebagai aktivitas social (talking) maupun alat bantu berpikir (writing) yaitu potensi yang mendapat dukungan para pakar agar terus dimunculkan dan ditumbuhkembangkan di kalangan siswa. ${ }^{5}$

Oleh sebab itu, perlu kepada guru mengetahui bagaimana cara menumbuhkembangkan kemampuan komunikasi matematik di kalangan

\footnotetext{
${ }^{4}$ Hasratuddin, Mengapa Harus Belajar Matematika, ( Medan: Perdana Mulya Sarana, 2015), hlm. 115.

${ }^{5}$ Ibid, hlm. 6-8.
} 
siswanya. Faktor yang lain perlu diperhartikan berkaitan dengan kesiapan guru mengaplikasikan kemampuan ini dalam kelas adalah perhatian kepala sekolah, pengawas, dan stakeholder lainnya untuk dapat membantu mempercepat sosialisasi.

Yang menjadi Indikator kemapuan matematis antara lain:

a. Mengaitkan benda real, gambar, dan bagan ke dalam bahasa matematika.

b. Mengeluarkan gagasan, keadaan, dan relasi matematika secara lisan atau tulisan, dengan benda real, grafik, gambar dan aljabar.

c. Menyatakan peristiwa dalam kegiatan sehari-hari dalam Bahasa matematika.

d. Menulis dan mendengarkan tentang matematika.

e. Membaca dengan persepsi suatu penerapan matematika tertulis.

f. Merancang pertanyaan tentang matematika yang sesuia dengan keadaan masalah.

g. Membuat relasi, menyusun pendapat, menyusun defenisi dan generalisasi. ${ }^{6}$

Beberapa Strategi Pembelajaran Yang Mendukung Kemampuan Komunikasi Matematik adalah sebagai berikut:

\section{Strategi Small-Group Work}

Strategi Small-Group Work, yaitu pada saat guru menyuruh siswa untuk bekerja bersama-sama dalam suatu kelompok, daripada guru memaparkan persoalan ini di depan kelas (secara klasikal/konvensional). Group Work dapat dilihat sebagai suatu perpaduan dari diskusi seluruh kelas (whole class discution) untuk melengkapi diskusi, namun keberhasilan group work tergantung dari banyaknya faktor yang dapat membantu kegiatan diskusi di kelas, misalnya:

${ }^{6}$ Karunia Eka Lestari dan Mokhammad Ridwan Yudhanegara, Penelitian Pendidikan Matematika (Bandung: Refika Aditama, 2015), hlm. 83. 
1. Fokus pemebalajaran bagi siswa harus jelas

2. Persiapan siswa harus maksimal

3. Bimbingan guru yang harus ada

4. Pemberian arahan, tetapi guru tidak mengintervensi

5. Monitoring atau kontrol dan feedback oleh guru

6. Pengelolaan waktu yang tepat dan kesimpulan yang masuk akal. ${ }^{7}$

Jika digunakan secara efektif dan efisien, strategi Small-Group Work banyak didapatkan kelebihannya dibandingkan dengan pembelajaran langsung, diskusi yang dilakukan pada grup besar dan bekerja secara indivudu, yaitu:

1. Group work membolehkan merubah materi pelajaran sesuai dengan latar belakang perbedaan antar group.

2. Group work memotivasi siswa untuk secara verbalisme mengeluarkan idenya, dan ini dapat membantu mereka memahami materi pelajaran.

3. Beberapa siswa akan sangat efektif dalam menjelaskan gagasannya kepada yang lain dalam bahasa yang mudah mereka pahami. Ini dapat membantu pemahaman bagi anggota grup untuk ketuntasan materi pelajaran.

4. Group Work memberikan waktu kepada seluruh siswa untuk memberikan gagasan/pendapat dan menuntaskan materi dalam suasana lingkungan yang aman dan nyaman.

5. Group work melibatkan siswa secara aktif dalam belajar dan ini dapat meningkatkan prestasi mereka serta retensi.

6. Group work membantu siswa belajar menghormati siswa yang lain baik yang pintar maupun yang lemah dan bekerjasama satu dengan yang lainnya.

\footnotetext{
${ }^{7}$ Bansu I. Ansari, Op. Cit, hlm. 81.
} 
Ada beberapa keterbatasan Strategi Small-Group Work, yaitu;

1. Siswa harus belajar bagaimana belajar

2. Sebagian siswa mungkin awalnya mendapatkan kesulitan seperti yang dialami anggota grup yang lainnya.

3. Jika di dalam pengawasan interaksi siswa dalam setiap kelompok, beberapa siswa akan menghabiskan waktu diskusi dengan persoalan yang tidak sesuai.

4. Sebagian siswa lebih senang belajar secara langsung dan kurang suka ketika guru menyuruh mereka atau belajar dengan teman sebaya.

5. Sebagian guru merasa tidak mudah mengawasi semua siswanya dalam kelompok. ${ }^{8}$

\section{Cooperative Learning}

Pembelajaran ini merupakan kegiatan pembelajaran kelompok yang diorganisir oleh satu prinsip bahwa pembelajaran harus didasarkan pada perubahan informasi secara sosial di antara kelompok-kelompok pembelajaran yang di dalamnya setiap pembelajar bertanggungjawab atas pembelajarannya sendiri dan didorong untuk meningkatkan pembelajaran anggota-anggota yang lain. ${ }^{9}$

Slavin mengungkapkan, bahwa pembelajaran koopertif merupakan strategi pembelajaran di mana siswa belajar dan bekerja secara berkolaborasi dalam suatu kelompok kecil terdiri atas 4-5 orang siswa dengan struktur kelompok heterogen. Pembelajaran koopertif ini bertujuan untuk mengembangkan prestasi akademis, keterampilan sosial, dan menanamkan sikap toleransi dan penerimaan terhadap keanekaragaman individu.

Ada beberapa tipe dari pembelajaran kooperatif ini, tetapi secara umum pembelajaran ini meliputi 4 sintaks berikut :

${ }^{8}$ Ibid, hlm. 82-83.

${ }^{9}$ Miftahul Huda, Coopertive Learning (Yogyakarta: Pustaka Pelajar, 2015), hlm. 29. 
1. Siswa dikelompokkan ke dalam beberapa kelompok di mana masing-masing kelompok terdiri atas siswa yang heterogen, dari segi kemampuan, ras, agama, dan lain-lain.

2. Siswa berintekrasi satu sama lain, baik atarsesama anggota kelompok maupun dengan kelompok lain dalam mengerjakan tugas yang diberikan guru.

3. Siswa mempresentasikan hasil diskusi kelompoknya serta mendiskusikannya dengan kelompok lain.

4. Guru memberrikan reward kepada siswa/kelompok siswa yng unggul dalam belajar serta memberikan motivasi siswa lain suapaya dapat mencapai prestasi akademik sesuai dengan yang diharapkan. ${ }^{10}$

Kelebihan pembelajaran koperatif, antara lain:

1. Pembelajaran koperatif menjadikan siswa yakin pada guru, lebih percaya lagi pada kemampuan diri sendiri untuk berpikir, mencari informasi dari sumber lain, dan belajar dari teman yang lain.

2. Pembelajaran koperatif memotivasi siswa untuk mengutarakan gagasan secara verbal dan membadingkannya dengan gagasan teman yang lain.

3. Pembelajaran koperatif mambantu siswa belajar menghormati siswa yang pintar dan siswa yang kurang pintar dan dapat menerima perbedaan ini.

4. Pembelajaran koperatif suatu strategi efektif bagi siswa untuk mencapai hasil belajar dan sosial termasuk meningkatkan prestasi, percaya diri, dan hubungan social sesama siswa.

5. Pembelajaran koperatif memberikan kesempatan kepada siswa untuk meningkatkan keterampilan bertanya dan memberikan komentar berbagai ragam problematika.

\footnotetext{
${ }^{10}$ Karunia Eka Lestari dan Mokhammad Ridwan Yudhanegara, Op. Cit, hlm. 44.
} 
Kelemahan pembelajaran koperatif, yaitu:

1. Sebagian siswa bisa saja pada awalanya segan mengeluarkan pendapat, takut dinilai temannya dalam kelompok.

2. Tidak semua siswa secara otomatis dapat memahami dan menerima philosophi pemebelajaran koperatif ini.

3. Pengaplikasian pemebelajaran koperatif dapat menghabiskan waktu menghitung hasil kemampuan kelompok.

4. Sukar membentuk kelompok yang dapat bekerja sama secara kompak

5. Penilaian individual menjadi sulit, karena tersembunyi di belakang kelompok. ${ }^{11}$

\section{Strategi Think-Pair-Share}

Sebagai salah satu solusi pembelajaran yang inovatif diharapkan dapat mengembangkan kemampuan berkomunikasi dan proses interaksi antar siswa adalah model pembelajaran diskusi kelas dengan strategi "Think-Pair-Share”. Strategi ini merupakan pembelajaran yang dapat meningkatkan partisipasi siswa dan cukup mudah diterapkan di kelas. Strategi ini juga merupakan cara yang efektif untuk meningkatkan daya fikir siswa.

Keutamaan mengajar dengan menggunakan think-pair-share (saling bertukar pikiran secara berpasangan) adalah sebagai berikut:

1. Dapat membuat pemikiran siswa menjadi luas dan menyatukan aspek-aspek kognitif dan aspek-aspek sosial dalam pembelajaran.

2. Dapat menimbulkan keterlibatan dan keikutsertaan siswa dengan memberikan kesempatan yang terbuka lebar pada siswa untuk berbicara dan mengungkapkan idenya sendiri dan memotivasi siswa untuk aktif dalam diskusi di kelas.

3. Dapat dimanfaatkan untuk menganalisis proses berpikir siswa dan mempelajari keterampilan berkomunikasi.

\footnotetext{
${ }^{11}$ Bansu I. Ansari, Op. Cit, hlm. 88-90.
} 
4. Dapat memadukan beberapa penadapat dan pemikiran dalam menentukan langkah-langkah penyelesaian masalah jika dilakukan secara berkelompok, diskusi

5. Meningkatkan berpikir kritis dan bersikap terbuka, yaitu mau menerima kebenaran atas dasar kenyataan. ${ }^{12}$

Beberapa tahapan pembelajaran think-pair-share, yaitu:

1. Guru memberikan suatu permasalahan yang menumbuhkan kemampuan berpikir siswa. Siswa memikirkan jawaban dari permasalahan yang diajukan secra mandiri.

2. Guru memberikan arahan kepada siswa untuk berpasangan dan mendiskusiakn apa yang telah dipikirkan.

3. Siswa berbagi ilmu pengetahuan yang diperoleh dari hasil. ${ }^{13}$

\section{Strategi Think-Talk-Write}

Strategi think-talk-write yaitu suatu strategi diharapkan dapat memunculkan dan meningkatkan kemampuan pemahaman dan komunikasi matematik siswa. Startegi ini pada dasarnya diperoleh melalui proses berpikir, berbicara, dan menulis. Proses kemajuan srtategi think-talk-write dimulai dari keterlibatan siswa dalam proses berpikir atau berkomunikasi dengan dirinya sendiri setelah proses membaca, selanjutnya berbicara membagi gagasan (sharing) dengan anggota sekelompok sebelum menulis. Keadaan seperti ini lebih efektif dilakukan dalam grup heterogen dengan 3-5 siswa. Dalam grup ini siswa diminta membaca, membuat catatan kecil, kemudian menjelaskan, mendengar dan aktivitas membagi ide barsama teman diskusinya kemudian mengungkapkannya melalui tulisan.

${ }^{12}$ Bansu I. Ansari, Op. Cit, hlm. 92-93.

${ }^{13}$ Karunia Eka Lestari dan Mokhammad Ridwan Yudhanegara, Op. Cit, hlm. 52. 
Aktivitas berpikir (think) dapat diperoleh dari proses membaca suatu teks matematik atau berisi cerita matematik kemudian membuat catatan apa yang telah mereka baca. Ketika membuat catatan mempertinggi pemahaman siswa, bahkan dapat meningkatkan keterampilan berpikir dan menulis. Salah satu manfaat dari tahap ini adalah, membuat catatan menjadi bagian integral dalam perencanaan pembelajaran.

Setelah kegiatan "think" selesai, dilanjutkan dengan tahap berikutnya "talk" yaitu berkomunikasi dengan menggunakan kata-kata dan bahasa yang mereka pahami. Pada tahapan ini memungkinkan siswa untuk terampil berbicara. Misalnya siswa berkomunikasi tentang gagasan matematik yang dihubungkan dengan pengalaman siswa, sehingga siswa mampu untuk menulis tentang ide itu. Selain dari itu, berkomunikasi dalam suatu diskusi dapat membantu kerjasama dan meningkatkan kegiatan belajar dalam kelas. Oleh sebab itu, keterampilan berkomunikasi dapat mempercepat kemampuan siswa mengungkapkan gagasannya melalui tulisan. Kemudian berkomunikasi baik antar siswa maupun dengan guru dapat meningkatkan pemahaman mereka. Hal ini bisa terjadi karena ketika siswa diberi kesempatan untuk berbicara atau berdialog, sekaligus mengkontruksi berbagai ide untuk dikemukakan melalui dialog atau diskusi.

Kemudian fase "write" yaitu menulis hasil diskusi pada lembar kerja yang telah disediakan (Lembar Aktivitas Siswa). Kegiatan menulis berarti mengkontruksi gagasan, karena setelah berdialog antar teman kemudian mengungkapkannya melaui tulisan. Menulis dalam matematika membantu mengaplikasikan salah satu tujuan pembelajaran, yaitu pemahaman siswa tentang materi yang telah pelajari. Kegiatan menulis membantu siswa dalam membuat hubungan dan juga memungkinkan guru melihat pengembangan konsep siswa. Selain itu, kegiatn menulis siswa bagi guru dapat meninjau (1) kesalahan siswa, miskonsepsi, dan pemahaman siswa terhadap ide yang keliru, (2) keterangan real dari prestasi siswa. ${ }^{14}$

\footnotetext{
${ }^{14}$ Bansu I. Ansari, Op. Cit, hlm. 100-104.
} 
Kegiatan menulis siswa juga dapat melihat dan membuat kaitan antara gagasan, mengembangkan ide-ide yang telah dikemukakan, menenelusuri jalan pikiran yang ditempuh otak agar mencapai suatu konsep, memvisualkan hal-hal khusus dan mengingatnya kembali dengan mudah. ${ }^{15}$

Sintaks dalam pembelajaran think-talk-write, adalah:

1. Membentuk kelompok yang tediri atas 4-5 orang anggota yang heterogen

2. Kegiatan berpikir di mana siswa membacakan teks berupa soal. Pada sintaks ini, siswa secara individu, memikirkan solusi jawaban (strategi penyelesaian), membuat catatan kecil tentang ide-ide yang terdapat pada bacaan, atau hal-hal yang tidak dipahaminya sesuai dengan bahasanya sendiri.

3. Kegiatan berbicara, siswa merefleksikan, menyusun, serta menguji pendapat-pendapat dalam kegiatan diskusi kelompok.

Siswa secara individu merumuskan pengetahuan yaitu jawaban atas soal (berisi landasan dan keterkaitan konsep, strategi, dan solusi) dalam bentuk tulisan (write) dengan bahasanya mereka. Di dalam tulisan itu, siswa menghubungkan pendapat-pendapat yang didapatkannya melalui diskusi kelompok. ${ }^{16}$

\section{B. KESIMPULAN}

Dari pemaparan di atas dapat disimpulkan sebagai berikut:

1. Salah satu solusi menumbuhkembangkan kemampuan komunikasi matematik di kalangan siswa di kelas yaitu dengan menerapkan startegi pembelajaran yang mendukung kemapuan komunikasi matematik.

\footnotetext{
${ }^{15}$ Bobbi Deporter dan Mike Hernacki, Quantum Learning (Bandung: MMU, 2011), hlm. 177.

${ }^{16}$ Karunia Eka Lestari dan Mokhammad Ridwan Yudhanegara, Op. Cit, hlm. 55.
} 
2. Strategi pembelajaran yang mendukung kemampuan komunikasi matematik diantaranya adalah: Strategi Small-Group Work, Cooverative Learning, Strategi Think-Pair-Share, dan Strategi Think-Talk-Write.

3. Strategi Small-Group Work adalah ketika guru menyuruh siswa bekerja sama dalam suatu kelompok.

4. Cooverative Learning adalah strategi pembelajaran di mana siswa belajar dan bekerja secara kolabolaratif dalam suatu kelompok kecil terdiri atas 4-5 orang siswa dengan struktur kelompok heterogen.

5. Strategi Think-Pair-Share yaitu salah satu jenis pembelajaran koperatif yang memicu kegiatan berpikir siswa secara berpasangan dan berbagi pengetahuan kepada siswa lainnya.

6. Strategi Think-Talk-Write yaitu salah satu jenis pembelajaran koperatif yang menekankan pada aktivitas berpikir, menyusun, menguji, merefleksikan dan menuliskan ide-ide.

7. Strategi Think-Talk-Write yaitu salah satu jenis pembelajaran koperatif yang menekankan pada aktivitas berpikir, menyusun, menguji, merefleksikan dan menuliskan ide-ide.

\section{DAFTAR PUSTAKA}

Bansu I. Ansari, Komunikasi Matematik, Strategi Berpikir dan Manajemen Belajar, Banda Aceh: Yayasan Pena, 2016.

Bobbi Deporter dan Mike Hernacki, Quantum Learning, Bandung: MMU, 2011.

Hamzah, B. Uno, Model Pembelajaran Menciptakan Proses Belajar Mengajar Yang Kreatif dan Efektif, Jakarta: Bumi Aksara, 2008.

Hasratuddin, Mengapa Harus Belajar Matematika, Medan: Perdana Mulya Sarana, 2015.

Karunia Eka Lestari dan Mokhammad Ridwan Yudhanegara, Penelitian Pendidikan Matematika, Bandung: Refika Aditama, 2015. 
68 Strategi Pembelajaran..........Rahma Hayati Siregar

Miftahul Huda, Coopertive Learning, Yogyakarta: Pustaka Pelajar, 2015.

Raodatol Jannah, Membuat Anak Cinta Matematika dan Eksak Lainnya, Jogyakarta: Diva Press, 2011. 